\title{
PERAN BRAND IMAGE DALAM MEMEDIASI PENGARUH KUALITAS PRODUK TERHADAP KEPUTUSAN PEMBELIAN
}

\author{
Ni Made Dwi Sanjiwani ${ }^{1}$ \\ I Gst. A. Kt. Gd. Suasana ${ }^{2}$ \\ ${ }^{1.2}$ Fakultas Ekonomi dan Bisnis Universitas Udayana (Unud), Bali, Indonesia \\ email: dwisanjiwani12@icloud.com¹,agung_suasana@unud.ac.id ${ }^{2}$
}

\begin{abstract}
ABSTRAK
Tujuan dari penelitian ini untuk menguji peran brand image dalam memediasi pengaruh pengaruh kualitas produk terhadap keputusan pembelian pada produk Miniso di Kota Denpasar. Penelitian ini dilakukan di Kota Denpasar dengan menggunakan ukuran sampel sebesar 100 orang dengan metode purposive sampling. Pengumpulan data diperoleh dengan hasil penyebaran kuesioner dengan menggunakan yang diukur dengan skala Likert. Teknik analisis data yang digunakan dalam penelitian ini yaitu teknik analisis jalur (path analysis), dan disertai dengan uji sobel. Hasil penelitian diajukan bahwa kualitas produk berpengaruh signifikan terhadap keputusan pembelian pada produk Miniso, kualitas produk berpengaruh signifikan terhadap brand image pada produk Miniso, brand image berpengaruh signifikan terhadap keputusan pembelian pada produk Miniso, dan brand image mampu memediasi pengaruh kualitas produk terhadap keputusan pembelian. kualitas produk dan brand imageberpengaruh signifikan terhadap keputusan pembelian pada prodiuk Miniso di Kota Denpasar.
\end{abstract}

Kata Kunci: brand image, kualitas produk, keputusan pembelian

\begin{abstract}
The purpose of this study is to examine the role of brand image in mediating the effect of product quality on purchasing decisions on Miniso products in Denpasar City. This research was conducted in the city of Denpasar by using a sample size of 100 people with a purposive sampling method. Data collection was obtained by the results of questionnaires using the measured Likert scale. The data analysis technique used in this study is path analysis technique, and is accompanied by a sobel test. The results of the study proposed that product quality had a significant effect on purchasing decisions on Miniso products, product quality had a significant effect on the brand image of Miniso products, brand image had a significant effect on purchasing decisions on Miniso products, and brand image was able to mediate the effect of product quality on purchasing decisions. product quality and imagery brand have a significant influence on purchasing decisions at the Miniso study program in Denpasar City.

Keywords: brand image, product quality, purchasing decision
\end{abstract}




\section{PENDAHULUAN}

Perusahaan retail merupakan keseluruhan aktivitas bisnis yang terkait dengan penjualan dan pemberian layanan kepada konsumen. Industri retail semakin berubah seiring dengan pertumbuhan teknologi, perkembangan dunia usaha serta kebutuhan konsumen. Perusahaan ritel juga banyak terdapat di Indonesia khususnya di Bali. Beberapa perusahaan ritel di bali dapat dilihat pada Tabel 1 yang menunjukkan beberapa daftar perusahaan ritel di Bali.

\section{Tabel 1.}

Daftar Perusahaan Ritel di Bali

\begin{tabular}{lc}
\hline No. & Nama Perusahaan \\
\hline 1. & PT. Matahari Department Store Tbk \\
2. & PT. Sumber Alfaria Trijaya Tbk \\
3. & PT Ace Hardware Indonesia Tbk \\
4. & PT. Mitra Adiperkasa Tbk \\
5. & PT. Ramayana Lestari Sentosa Tbk \\
6. & Hipermarket \\
7. & Alfamidi \\
8. & CIRCLE K MINIMART \\
\hline
\end{tabular}

Sumber: CNN Indonesia tahun 2017

Tabel 1. menunjukkan daftar beberapa perusahaan ritel yang ada di Bali. Para retail asing melihat banyaknya penduduk di Bali sehingga dipandang sebagai pasar potensial, hal tersebut dapat dilihat pada Tabel 2. yang menunjukkan data jumlah penduduk Bali tiap Kabupaten.

Tabel 2.

Jumlah Penduduk tiap Kabupaten di Provinsi Bali Tahun 2018

\begin{tabular}{|c|c|}
\hline Kabupaten & Jumlah Penduduk \\
\hline Jembrana & 261.638 \\
\hline Tabanan & 420.913 \\
\hline Badung & 543.332 \\
\hline Gianyar & 469.777 \\
\hline Klungkung & 170.534 \\
\hline Bangli & 215.353 \\
\hline Karangasem & 396.487 \\
\hline Buleleng & 624.125 \\
\hline Denpasar & 788.589 \\
\hline
\end{tabular}

Sumber: Badan Pusat Statistik Provinsi Bali, 2018

Dilihat dari data menyatakan bahwa Bali dengan penduduk sebanyak 4.200.100 jiwa (Badan Pusat Statistik) menjadi salah satu target para pengusaha retail asing untuk membuka usahanya khususnya Denpasar yang merupakan Ibukota Provinsi Bali. Selain sebagai Ibu Kota Provinsi Bali, Denpasar merupakan Kabupaten yang memiliki jumlah penduduk terbanyak dari sembilan Kabupaten yang ada di Bali. Hal ini menjadi alasan mengapa perusahaan retail berkembang pesat di Denpasar. Berikut tabel perbandingan jumlah penduduk tiap Kabupaten di Bali.

Perusahaan retail di Bali khususnya di Denpasar berkembang dengan cepat. Banyaknya jumlah perusahaan retail menyebabkan adanya persaingan yang ketat 
antar perusahaan. Persaingan tersebut menyebabkan perusahaan retail perlu meningkatkan reputasi sebagai salah satu keunggulan daya saing. Reputasi merupakan perwujudan dari pengalaman seseorang dengan produk, ataupun pelayanan yang mereka dapatkan. Reputasi yang baik akan meningkatkan kredibilitas, membuat konsumen lebih percaya diri bahwa mereka akan mendapatkan apa yang telah dijanjikan kepada mereka. Reputasi menjadi jaminan bahwa konsumen akan mendapatkan sesuai ekpektasi yang mereka miliki. Pelanggan merupakan pihak luar yang memiliki hubungan erat dengan perusahaan, baik itu perusahaan jasa atau barang. Kualitas produk sangat mempengaruhi tingkat keputusan pembelian konsumen terhadap produk.

Keputusan konsumen untuk membeli suatu produk ditentukan dari kualitas dan harga barang tersebut. Kepuasan konsumen akan dipengaruhi dari harga produk tersebut apakah kualitas produk yang dibeli sesuai dengan nilai barang tersebut. Konsumen akan menggunakan sudut pendang mereka untuk menilai dan membuat keputusan dalam membeli produk yang berkualitas (Ackaradejruangsri, 2013). Keputusan pembelian merupakan sikap seseorang untuk membeli maupun menggunakan suatu produk baik berupa barang maupun jasa yang dianggap dapat memuaskan dirinya dan kesediaan bertanggung jawab atas risiko yang akan diambilnya. Pemahaman faktor-faktor psikologis dan pribadi konsumen sangatlah penting dan memiliki pengaruh yang kuat terhadap perilaku pembelian dan mengingatkan merek akan jasa, produk dan perusahaan (Afroz, 2013). Menurut (Mamang dan Sophia (2013: p. 332) menjelaskan bahwa pengambilan keputusan konsumen adalah proses pemecahan suatu masalah yang diarahkan pada sasaran. Keputusan pembelian yang diambil oleh seorang konsumen merupakan kumpulan dari banyaknya keputusan yang telah dibuat yang telah terorganisir dengan baik (Aldi, 2012). Proses keputusan pembelian menentukan langkah-langkah yang berbeda saat pelanggan membeli sebuah produk dari perusahaan. Langkahlangkah tersebut merupakan kebiasaan-unik yang dimiliki konsumen saat sebelum atau setelah membeli produk dan saat konsumen menggunakannya. Kebiasaankebisaan unik inilah yang akan menimbulkan niat terhadap produk, jasa, dan organisasi (Khandelwal et al., 2014).

Keputusan konsumen untuk membeli suatu produk selalu melibatkan aktivitas secara fisik (berupa kegiatan langsung konsumen melalui tahapantahapan proses pengambilan keputusan pembelian) dan aktivitas secara mental (yakni saat konsumen menilai produk sesuai dengan kriteria tertentu yang ditetapkan oleh individu). Perilaku konsumen sangat mempengaruhi keputusan pembelian terhadap suatu barang. Pembelian tercipta karena adanya needs (kebutuhan keperluan) atau wants (keinginan) atau campuran keduanya. Miniso sebagai perusahaan retail yang sedang berkembang bisa memenuhi kebutuhan dan keinginan konsumen atas sebuah produk yang berkualitas. Kualitas produk adalah atribut-atribut yang digunakan sebuah produk untuk memposisikan produk tersebut pada tingkatan tertentu sesuai dengan harga dan spesifikasi produk. Kualitas produk adalah senjata utama bagi perusahaan untuk bisa menarik konsumen. Dapat dijelaskan bahwa kualitas produk sebagai perwujudan hasil produk perusahaan yang menjembatani hubungan antara kuputusan pembelian pada produk dan Brand Image perusahaan. Pengalaman dari konsumen dalam 
memakai produk akan menghasilkan penilaian konsumen terhadap produk tersebut. Menurut penelitian yang dilakukan oleh Ghanimata dan Kamal (2012), Fatlahah (2013), Utama (2014), Karlina dan Seminari (2015) menyatakan bahwa kualitas produk berpengaruh positif terhadap keputusan pembelian. Penelitian ini berbanding terbalik pada penelitian yang dilakukan oleh Rawung, Oroh dan Sumarauw (2015) yang menyatakan bahwa kualitas produk tidak berpengaruh secara signifikan terhadap keputusan pembelian. Adanya penelitian sebelumnya yang bertentangan mengenai pengaruh kualitas produk terhadap keputusan pembelian sehingga penulis mencantumkan variabel yang memediasi yaitu brand image.

Brand Image sangat penting bagi suatu perusahaan untuk bisa meningkatkan kepercayaan diri konsumen saat menggunakan produknya. Brand Image besar pengaruhnya terhadap perkembangan perusahaan. Pembentukan image pada perusahaan bisa menjadi positif maupun menjadi negatif tergantung persepsi konsumen yang telah menggunakan produknya. Hal ini juga mempengaruhi tinggi rendahnya tingkat penjualan produk pada perusahaan. Banyak perusahaan berkembang setelah image positif ditanamkan pada merek perusahaan tersebut oleh konsumen sehingga menimbulkan peningkatan daya beli konsumen akan produk tersebut.

Brand Image menurut Kotler (2002: p. 215) adalah seperangkat keyakinan, ide, dan kesan yang dimiliki oleh seseorang terhadap suatu merek. Miniso merupakan salah satu merek yang sudah memiliki image yang prositif karena produknya dapat memuaskan kebutuhan konsumen. Karena itu sikap dan tindakan konsumen terhadap suatu merek sangat ditentukan oleh merek tersebut. Hingley, Walley, Lindgreen, Custance dan Taylor (2007) menyatakan bahwa merek menciptakan ide dengan menarik dan mempertahankan pelanggan sebagai hasil dari percampuran antara produk yang efektif, ciri khas, dan nilai tambah yang dibenak konsumen. Jadi, Brand Image (Citra Merek) merupakan suatu representasi dari keseluruhan persepsi yang dibentuk melalui informasi dan pengalaman masa lalu terhadap suatu merek tersebut. Sehingga Miniso yang merupakan retail yang dikelola oleh PT. Miniso Lifestyle Trading Indonesia merupakan retail yang menjadi salah satu pemain baru di Indonesia yang sangat berkembang. Citra merek terbentuk dari persepsi yang telah lama terdapat pada pikiran konsumen. Citra merek yang dimiliki oleh Miniso saat ini tidak lepas dari adanya kesederhaan dalam membuat nama merek sehingga konsumen mudah untuk mengenali dari merek dan produk Miniso dimanapun produk tersebut berada (Dabija, 2013). Hal ini sangat dipengaruhi oleh kualitas produk yang baik. Adanya kualitas produk yang medukung akan membuat image yang baik juga terhadap produk dan merek yang ada pada perusahaan. Hasil penelitian ini didukung oleh penelitian sebelumnya Nurdianto dan Yuniati (2013), Alfiyah dan Maftukhah (2015) menyimpulkan bahwa kualitas produk berpengaruh terhadap brand image.

Brand Miniso di Kota Denpasar sudah tidak asing lagi khususnya bagi Penduduk Kota Denpasar yang berusia remaja sampai dewasa. Dilihat dari hasil pra survey yang dilakukan oleh peneliti yang dilakukan pada 20 responden yang seluruhnya adalah mahasiswa, seluruh responden pernah berbelanja di Miniso. 18 
responden mengatakan puas terhadap kualitas produk dari Miniso sedangkan 2 responden mengatakan tidak merasa puas terhadap produk Miniso. Tingginya kepuasan pelanggan terhadap produk Miniso membuat pelanggan memutuskan untuk membeli kembali produk Miniso. Brand asal China ini membuka sebanyak 8 gerai di Bali untuk memenuhi kebutuhan dan keinginan pelanggannya. 8 gerai yang ada di Bali, 2 diantaranya berlokasi di Denpasar yaitu di Level21 Mall dan Plaza Renon. Miniso menawarkan produk-produk kebutuhan sehari-hari masyarakat yang dimulai dari aksesoris fashion seperti tas, dompet dan lainnya, alat kebutuhan rumah tangga seperti sendok, garpu, tempat minum dan lainnya, produk elektronik seperti headset hingga kosmetik seperti make up. Retail dengan konsep menjual barang murah namun bukan murahan ini banyak diminati oleh berbagai kalangan. Bagusnya kualitas yang ditawarkan pada produk Miniso ini mengakibatkan banyaknya masyarakat ingin memiliki dan membeli berbagai macam produk yang dijual oleh Miniso itu sendiri. Brand Miniso ini mempunyai pesaing yaitu Brand Daiso dengan produk dan kualitas yang ditawarkan juga sama persis dengan Miniso. Adanya pesaing pada Miniso tidak merubah konsumen untuk membeli produk dari Miniso, dikarenakan melekatnya image positif yang dimiliki oleh Miniso.

Keputusan pembelian adalah sebuah proses dimana konsumen mengenal masalahnya, mencari informasi mengenai produk atau merek tertentu dan mengevaluasi seberapa baik masing-masing alternatif tersebut dapat memecahkan masalahnya, yang kemudian mengarah kepada keputusan pembelian Tjiptono 2014 : p. 21). keputusan pembelian adalah suatu keputusan konsumen yang dipengaruhi oleh ekonomi keuangan, teknologi, politik, budaya, produk, harga, lokasi, promosi, physical evidence, people dan, process (Alma, 2013: p. 96). Sehingga membentuk suatu sikap pada konsumen untuk mengolah segala informasi dan mengambil kesimpulan berupa respons yang muncul produk apa yang akan dibeli. Keputusan pembelian yaitu "Consumer behavior is the study of how individual, groups, and organizations select, buy, use, and dispose of goods, services, ideas, or experiences to satisfy their needs and wants". Artinya, keputusan pembelian merupakan bagian dari perilaku konsumen yaitu studi tentang bagaimana individu, kelompok, dan organisasi memilih, membeli, menggunakan, dan bagaimana barang, jasa, ide atau pengalaman untuk memuaskan kebutuhan dan keinginan mereka (Armstrong, 2015: p. 177).

Dimensi dari keputusan pembelian menurut Kotler dan Keller (2016: p. 188) sebagai berikut: 1) Pilihan produk. Konsumen dapat mengambil keputusan untuk membeli sebuah produk atau menggunakan uangnya untuk tujuan yang lain. Dalam hal ini perusahaan harus memusatkan perhatiannya kepada orang-orang yang berminat membeli sebuah produk serta alternatif yang mereka pertimbangkan. 2) Pilihan merek. Konsumen harus mengambil keputusan tentang merek nama yang akan dibeli setiap merek memiliki perbedaan tersendiri. Dalam hal ini perusahaan harus mengetahui bagaimana konsumen memilih sebuah merek. 3) Pilihan penyalur. Konsumen harus mengambil keputusan tentang penyalur mana yang akan dikunjungi. Setiap konsumen berbeda-beda dalam hal menentukan penyalur bisa dikarenakan faktor lokasi yang dekat, harga yang murah, persediaan barang yang lengkap, kenyamanan dalam belanja, keluasan 
tempat dan lain- lain. 4) Waktu pembelian. Keputusan konsumen dalam pemilihan waktu pembelian bisa berbeda-beda misalnya ada yang membeli setiap hari, satu minggu sekali, dua minggu sekali dan lain sebagainya. 5) Jumlah pembelian. Konsumen dapat mengambil keputusan tentang seberapa banyak produk yang akan dibelanjakan pada suatu saat. Pembelian yang dilakukan mungkin lebih dari satu. Dalam hal ini perusahaan harus mempersiapkan banyaknya produk sesuai dengan keinginan yang berbeda-beda. 6) Metode pembayaran. Konsumen dapat mengambil keputusan tentang metode pembayaran yang akan dilakukan dalam pengambilan keputusan menggunakan produk atau jasa. Saat ini keputusan pembelian dipengaruhi oleh tidak hanya oleh aspek lingkungan dan keluarga, keputusan pembelian juga dipengaruhi oleh teknologi yang digunakan dalam transaksi pembelian.

Faktor-faktor yang menyebabkan terjadinya keputusan pembelian (Kotler \& Keller, 2016: p. 187) yaitu produk dan servis, harga, distribusi dan komunikasi. Selain empat faktor tersebut, ada faktor eksternal yang merupakan faktor lainnya yaitu ekonomi, teknologi, politik dan juga budaya. Kualitas produk sebagai berikut: "Product quality is the characteristics of a product or service that bear on its ability to satisfy stated or implied customer needs" (Armstrong, 2015: p. 253). Berdasarkan definisi tersebut dapat dijelaskan bahwa kualitas produk merupakan kemampuan suatu produk dalam memenuhi kebutuhan konsumen. Keinginan konsumen tersebut diantaranya daya tahan produk, keandalan produk, kemudahan pemakaian, serta atribut bernilai lainnya yang bebas dari kekurangan dan kerusakan.

Kualitas produk memiliki dimensi yang dapat digunakan untuk menganalisis karakteristik dari suatu produk. Menurut David Garvin dalam (Tjiptono, 2014: p. 134) kualitas produk memiliki delapan dimensi sebagai berikut: Performance (kinerja), merupakan karakteristik pokok dari produk inti (core product) yang dibeli. Features (fitur atau ciri-ciri tambahan), yaitu karaktersitik sekunder atau pelengkap. Reliability (reliabilitas), yaitu kemungkinan kecil akan mengalami kerusakan atau gagal dipakai. Confermance to Specifications (kesesuaian dengan spesifikasi), yaitu sejauh mana karakteristik desain dan operasi memenuhi standar-standar yang telah ditetapkan sebelumnya. Durability (daya tahan), yaitu berkaitan dengan berapa lama produk tersebut dapat digunakan. Serviceability, meliputi kecepatan, kompetensi, kenyamanan, kemudahan direparasi; serta penanganan keluhan secara memuaskan. Esthetics (Estetika), yaitu daya tarik produk terhadap panca indera. Perceived Quality (kualitas yang dipersepsikan), yaitu citra dan reputasi produk serta tanggung jawab perusahaan terhadapnya.

Brand image adalah representasi dari keseluruhan persepsi terhadap suatu merek dan dibentuk dari informasi-informasi dan pengalaman dari masa lalu terhadap merek tersebut. Citra merek produk merupakan asset perusahaan dalam melanjutkan pemasaran suatu produk (Dewi \& Suasana, 2014). Menurut Vanessa dan Arifin (2017) citra merek merupakan kepercayaan yang dibuat dibenak konsumen untuk menjadi pembeda dari merek yang lainnya seperti misalnya lambang, desain huruf, dan juga desain dari warna. Brand image itu sendiri memiliki arti kepada suatu pencitraan sebuah produk dibenak konsumen secara 
massal. Setiap orang akan memiliki pencitraan yang sama terhadap sebuah merek. Persaingan dunia industri yang semakin ketat saat ini, menuntut perusahaan untuk lebih kreatif dan membuat suatu keunggulan yang kompetitif, baik itu dari segi kemasan, produk, saluran pemasaran maupun citranya, jika tanggapan konsumen tentang penawaran suatu produk yang bersaing tetap sebagai suatu hal yang sama atau biasa, maka konsumen akan melihat merek dari suatu produk dengan tanggapan yang berbeda.

Citra Korporat. Citra yang ada dalam perusahaan itu sendiri. Perusahaan sebagai organisasi berusaha membangun imagenya dengan tujuan tak lain ingin agar nama perusahaan bagus, sehingga akan mempengaruhi segala hal mengenai apa yang dilakukan oleh perusahaan tersebut. Citra Produk. Citra konsumen terhadap suatu produk yang dapat berdampak positif maupun negative yang berkaitan dengan kebutuhan, keinginan, dan harapan konsumen. Image dari produk dapat mendukung terciptanya sebuah brand image atau citra dari merek tersebut. Citra Pemakai. Citra pemakai dapat dibentuk langsung dari pengalaman dan kontak dengan pengguna dari merek tersebut. Manfaat adalah nilai pribadi konsumen yang diletakkan terhadap atribut dari produk atau layanan yaitu apa yang konsumen pikirkan akan konsumen dapatkan dari produk atau layanan tersebut.

Keterlibatan konsumen terhadap pembelian dipengaruhi oleh variabel kualitas produk, brand image dan keputusan pembelian. Level keterlibatan ini selain mempengaruhi persepsi juga mempengaruhi fungsi memori pada konsumen. Hal ini menjadi faktor yang kuat bagi konsumen untuk memutuskan akan membeli atau tidak terhadap produk tersebut. Semakin kuat persepsi yang dibuat oleh konsumen mengenai brand image semakin besar keputusan pembelian pada produk tersebut. Menurut penelitian dari Mendrofa (2010), Fristiana (2012), Malik (2013), Musay (2013) menyimpulkan bahwa brand image berpengaruh signifikan terhadap keputusan pembelian. Dengan penelitian tersebut kuatnya peran brand image pada suatu perusahaan sangat mendukung keputusan pembelian yang dilakukan oleh konsumen terhadap produk yang ditawarkan oleh konsumen.

Kualitas produk memiliki dimensi yang dapat digunakan untuk menganalisis karakteristik dari suatu produk. Menurut David Garvin dalam Tjiptono (2016: p. 134) kualitas produk memiliki delapan dimensi sebagai berikut: Performance (kinerja), merupakan karakteristik pokok dari produk inti (core product) yang dibeli. Features (fitur atau ciri-ciri tambahan), yaitu karaktersitik sekunder atau pelengkap. Reliability (reliabilitas), yaitu kemungkinan kecil akan mengalami kerusakan atau gagal dipakai. Confermance to Specifications (kesesuaian dengan spesifikasi), yaitu sejauh mana karakteristik desain dan operasi memenuhi standar-standar yang telah ditetapkan sebelumnya. Durability (daya tahan), yaitu berkaitan dengan berapa lama produk tersebut dapat digunakan. Serviceability, meliputi kecepatan, kompetensi, kenyamanan, kemudahan direparasi; serta penanganan keluhan secara memuaskan. Esthetics (Estetika), yaitu daya tarik produk terhadap panca indera. Perceived Quality (kualitas yang dipersepsikan), yaitu citra dan reputasi produk serta tanggung jawab perusahaan terhadapnya. 
Santoso (2013), Saidani dan Arifin (2012), Yoher dan Santika (2018), Fernando dan Aksari (2018) dalam penelitiannya menyatakan bahwa kualitas produk (product quality) berpengaruh signifikan terhadap keputusan pembelian konsumen. Penelitian tersebut berbeda dengan penelitian yang dilakukan oleh Rawung et al. (2015) yang menyatakan bahwa produk tidak berpengaruh secara signifikan terhadap keputusan pembelian. Berdasarkan hal tersebut diajukan hipotesis sebagai berikut:

$\mathrm{H}_{1}$ : Kualitas produk berpengaruh signifikan terhadap keputusan pembelian.

Brand Image menurut Kotler 2002: p. 215) adalah seperangkat keyakinan, ide, dan kesan yang dimiliki oleh seseorang terhadap suatu merek. Miniso merupakan salah satu merek yang sudah memiliki image yang prositif karena produknya dapat memuaskan kebutuhan konsumen. Karena itu sikap dan tindakan konsumen terhadap suatu merek sangat ditentukan oleh merek tersebut. Hingley et al. (2007) menyatakan bahwa merek menciptakan ide dengan menarik dan mempertahankan pelanggan sebagai hasil dari percampuran antara produk yang efektif, ciri khas, dan nilai tambah yang dibenak konsumen. Jadi, Brand Image (Citra Merek) merupakan suatu representasi dari keseluruhan persepsi yang dibentuk melalui informasi dan pengalaman masa lalu terhadap suatu merek tersebut. Sehingga Miniso yang merupakan retail yang dikelola oleh PT. Miniso Lifestyle Trading Indonesia merupakan retail yang menjadi salah satu pemain baru di Indonesia yang sangat berkembang. Citra merek terbentuk dari persepsi yang telah lama terdapat pada pikiran konsumen. Citra merek yang dimiliki oleh Miniso saat ini tidak lepas dari adanya kesederhaan dalam membuat nama merek sehingga konsumen mudah untuk mengenali dari merek dan produk Miniso dimanapun produk tersebut berada (Dabija, 2013). Hal ini sangat dipengaruhi oleh kualitas produk yang baik. Adanya kualitas produk yang medukung akan membuat image yang baik juga terhadap produk dan merek yang ada pada perusahaan. Hasil penelitian ini didukung oleh penelitian sebelumnya Nurdianto dan Yuniati (2013), Alfiyah dan Maftukhah (2015) menyimpulkan bahwa kualitas produk berpengaruh terhadap brand image. Noerchoidah (2013), Nurdianto dan Yuniati (2013), Karlina dan Seminari (2015) pada penelitiannya dapat disimpulkan bahwa kualitas produk berpengaruh signifikan terhadap brand image. Berdasarkan hal tersebut diajukan hipotesis sebagai berikut:

$\mathrm{H}_{2}$ : Kualitas produk berpengaruh signifikan terhadap brand image

Fristiana (2012), Malik et al. (2013), Sandhu (2014), Dewi dan Aksari (2017), Arsyanto dan Rahmawati (2018) pada penelitiannya menyimpulkan bahwa brand image berpengaruh signifikan terhadap keputusan pembelian. Berdasarkan hal tersebut diajukan hipotesis sebagai berikut:

$\mathrm{H}_{3}$ : Brand image berpengaruh signifikan terhadap keputusan pembelian

Keputusan konsumen untuk membeli suatu produk selalu melibatkan aktivitas secara fisik (berupa kegiatan langsung konsumen melalui tahapantahapan proses pengambilan keputusan pembelian) dan aktivitas secara mental (yakni saat konsumen menilai produk sesuai dengan kriteria tertentu yang ditetapkan oleh individu). Perilaku konsumen sangat mempengaruhi keputusan pembelian terhadap suatu barang. Pembelian tercipta karena adanya needs (kebutuhan keperluan) atau wants (keinginan) atau campuran keduanya. Miniso 
sebagai perusahaan retail yang sedang berkembang bisa memenuhi kebutuhan dan keinginan konsumen atas sebuah produk yang berkualitas. Kualitas produk adalah atribut-atribut yang digunakan sebuah produk untuk memposisikan produk tersebut pada tingkatan tertentu sesuai dengan harga dan spesifikasi produk. Kualitas produk adalah senjata utama bagi perusahaan untuk bisa menarik konsumen. Dapat dijelaskan bahwa kualitas produk sebagai perwujudan hasil produk perusahaan yang menjembatani hubungan antara kuputusan pembelian pada produk dan Brand Image perusahaan. Pengalaman dari konsumen dalam memakai produk akan menghasilkan penilaian konsumen terhadap produk tersebut. Menurut penelitian yang dilakukan oleh Ghanimata dan Kamal (2012), Fatlahah (2013), Utama (2014), Karlina dan Seminari (2015) menyatakan bahwa kualitas produk berpengaruh positif terhadap keputusan pembelian. Penelitian ini berbanding terbalik pada penelitian yang dilakukan oleh Rawung et al. (2015) yang menyatakan bahwa kualitas produk tidak berpengaruh secara signifikan terhadap keputusan pembelian. Adanya penelitian sebelumnya yang bertentangan mengenai pengaruh kualitas produk terhadap keputusan pembelian sehingga penulis mencantumkan variabel yang memediasi yaitu brand image. Sagita (2013) dan Fianto (2014) pada menelitian dapat disimpulkan bahwa citra merek memiliki pengaruh signifikan terhadap keputusan pembelian. Nurdianto dan Yuniati (2013), Alfiyah dan Maftukhah (2015) dalam penelitiannya menyatakan bahwa kualitas produk yang baik akan memberikan kepercayaan dan persepsi (citra) yang baik juga kepada konsumen dalam penggunaan produk yang kemudian menjadi motivasi terhadap konsumen untuk membuat keputusan pembelian. Berdasarkan hal tersebut diajukan hipotesis sebagai berikut:

$\mathrm{H}_{4}$ : Brand Image mampu memediasi kualitas produk terhadap keputusan pembelian

\section{METODE PENELITIAN}

Penelitian ini dilakukan di Kota Denpasar. Kota Denpasar dipilih karena Kota Denpasar merupakan kabupaten yang memiliki penduduk terpadat dari delapan Kabupaten lainnya di Bali. Mengingat saat ini, Kota Denpasar mengalami peningkatan insfrastruktur, perkembangan bisnis, maupun perkembangan jumlah penduduk sehingga meningkatkan jumlah retail di Kota Denpasar. Ruang lingkup penelitian ini adalah brand image, kualitas produk dan keputusan pembelian pada produk Miniso. Peningkatan jumlah retail di Kota Denpasar dinilai sesuai untuk dijadikan lokasi penelitian.

Populasi pada penelitian ini adalah seluruh konsumen yang pernah membeli dan menggunakan produk Miniso di Kota Denpasar. Metode penentuan sampel yang digunakan yaitu non probability sampling yaitu teknik pengambilan sampel yang tidak memberi peluang atau kesempatan yang sama bagi setiap unsur atau anggota populasi untuk dipilih menjadi sampel. Teknik non probability sampling yang dipilih adalah purposive sampling.

Teknik analisis data yang digunakan dalam penelitian ini yaitu analisis jalur (Path Analysis).

Hipotesis 1 memiliki persamaan struktural 1 sebagai berikut :

$$
\mathrm{M}=\beta_{1} \mathrm{X}+\mathrm{e}
$$


Hipotesis 2 memiliki persamaan struktural 2 sebagai berikut :

$$
\mathrm{M}=\beta_{2} \mathrm{X}+\beta_{3} \mathrm{Y}_{1}+\mathrm{e}
$$

Keterangan :

$$
\begin{array}{ll}
\mathrm{X} & =\text { Kualitas produk } \\
\mathrm{Y}_{1} & =\text { Brand image } \\
\mathrm{Y}_{2} & =\text { Keputusan pembelian } \\
\beta_{2} \beta_{2} \beta_{2} & =\text { Koefisien regresi variabel } \\
\mathrm{e} & =\text { error }
\end{array}
$$

Tabel 3.

Variabel dan Indikator Variabel Penelitian

\begin{tabular}{lllll}
\hline \multicolumn{1}{c}{ Nama Variabel } & & \multicolumn{1}{c}{ Indikator } & Simbol & \multicolumn{1}{c}{ Sumber } \\
\hline Keputusan & 1) & Pilihan Terhadap Produk & $\mathrm{Y}_{2.1}$ & Kotler \& Amstrong \\
Pembelian $\left(\mathrm{Y}_{2}\right)$ & 2) & Pilihan Terhadap Merek & $\mathrm{Y}_{2.2}$ & $(2016: 188)$ \\
& 3) & Pilihan Terhadap Penyalur & $\mathrm{Y}_{2.3}$ & \\
& 4) & Jumlah Pembelian & $\mathrm{Y}_{2.4}$ & \\
Kualitas & 5) & Metode Pembayaran & $\mathrm{Y}_{2.5}$ & \\
Produk (X) & 1) & Kinerja Produk & $\mathrm{X}_{1}$ & Tjiptono (2016:134) \\
& 2) & Fitur Tambahan Produk & $\mathrm{X}_{2}$ & \\
& 3) & Reliabilitas Produk & $\mathrm{X}_{3}$ & \\
& 4) & Kesesuaian Produk & $\mathrm{X}_{4}$ & \\
& 5) & Daya Tahan Produk & $\mathrm{X}_{5}$ & \\
Brand & 6) & Kenyamanan Produk & $\mathrm{X}_{6}$ & \\
Image (Y1) & 7) & Estetika Produk & $\mathrm{X}_{7}$ & \\
& 8) & Persepsi Kualitas Produk & $\mathrm{X}_{8}$ & \\
& 1) & Logo & $\mathrm{Y}_{1.1}$ & Tobing (2013:6) \\
& 2) & Word of Mouth & $\mathrm{Y}_{1.2}$ & Sulistyari (2012) \\
& 3) & Reputation & $\mathrm{Y}_{1.3}$ & \\
& 4) & Citra Corporat & $\mathrm{Y}_{1.4}$ & \\
& 5) & Citra Produk & $\mathrm{Y}_{1.5}$ & \\
& 6) & Citra Pemakai & $\mathrm{Y}_{1.6}$ & \\
\hline
\end{tabular}

Sumber: Data diolah, 2018

\section{HASIL DAN PEMBAHASAN}

Penduduk Kota Denpasar yang berusia remaja sampai dewasa. Dilihat dari hasil pra survey yang dilakukan oleh peneliti yang dilakukan pada 20 responden yang seluruhnya adalah mahasiswa, seluruh responden pernah berbelanja di Miniso. 18 responden mengatakan puas terhadap kualitas produk dari Miniso sedangkan 2 responden mengatakan tidak merasa puas terhadap produk Miniso. Tingginya kepuasan pelanggan terhadap produk Miniso membuat pelanggan memutuskan untuk membeli kembali produk Miniso. Brand asal China ini membuka sebanyak 8 gerai di Bali untuk memenuhi kebutuhan dan keinginan pelanggannya. 8 gerai yang ada di Bali, 2 diantaranya berlokasi di Denpasar yaitu di Level21 Mall dan Plaza Renon. Miniso menawarkan produk-produk kebutuhan sehari-hari masyarakat yang dimulai dari aksesoris fashion seperti tas, dompet dan lainnya, alat kebutuhan rumah tangga seperti sendok, garpu, tempat minum dan 
lainnya, produk elektronik seperti headset hingga kosmetik seperti make up. Retail dengan konsep menjual barang murah namun bukan murahan ini banyak diminati oleh berbagai kalangan. Bagusnya kualitas yang ditawarkan pada produk Miniso ini mengakibatkan banyaknya masyarakat ingin memiliki dan membeli berbagai macam produk yang dijual oleh Miniso itu sendiri. Brand Miniso ini mempunyai pesaing yaitu Brand Daiso dengan produk dan kualitas yang ditawarkan juga sama persis dengan Miniso.

Penelitian ini merupakan penelitian menggunakan 100 orang sebagai reponden sesuai dengan ukuran sampel yang digunakan. Responden penelitian digambarkan dengan menyajikan karakteristiknya berdasarkan variabel demografi yaitu umur, jenis kelamin, pekerjaan, frekuensi pembelian dan jumlah jenis produk yang dibeli dapat disajikan pada tabel 3 sebagai berikut:

Tabel 4.

Karakteristik Responden

\begin{tabular}{|c|c|c|c|c|}
\hline No. & Variabel & Klasifikasi & $\begin{array}{l}\text { Jumlah } \\
\text { (orang) }\end{array}$ & $\begin{array}{c}\text { Persentase } \\
(\%)\end{array}$ \\
\hline & & $\leq 22$ & 70 & 70 \\
\hline \multirow[t]{4}{*}{1} & Umur & $23-28$ & 23 & 23 \\
\hline & & $>28$ & 7 & 7 \\
\hline & \multicolumn{2}{|l|}{ Jumlah } & 100 & 100 \\
\hline & & Laki-laki & 17 & 17 \\
\hline \multirow[t]{3}{*}{2} & Jenis Kelamin & Perempuan & 83 & 83 \\
\hline & Jumlah & & 100 & 100 \\
\hline & & Mahasiswa/Pelajar & 59 & 59 \\
\hline \multirow[t]{3}{*}{3} & Pekerjaan & ASN/TNI-POLRI & 25 & 25 \\
\hline & & Karyawan/Wiraswasta & 16 & 16 \\
\hline & \multicolumn{2}{|l|}{ Jumlah } & 100 & 100 \\
\hline
\end{tabular}

Sumber: Data diolah, 2018

Berdasarkan data karakteristik responden yang ada pada Tabel 4. bahwa mengenai klasifikasi umur mayoritas responden berumur $\leq 22$ tahun yakni sebesar 70 persen, dan kemudian diikuti oleh kelompok umur 23-28 tahun sebesar 23 persen dan $>28$ tahun sebesar 7 persen. Perbedaan yang cukup signifikan karena masyarakat dengan usia $\leq 22$ tahun ini tergolong dalam usia remaja yang akan terbuka dengan informasi-informasi mengenai hal-hal baru dan selain itu pada usia tersebut juga mudah dipengaruhi oleh faktor eksternal diantaranya yaitu keluarga dan teman yang bisa mempengaruhi dan memutuskan untuk membeli suatu produk. Selanjutnya jika dilihat dari klasifikasi jenis kelamin cenderung didominasi oleh perempuan yakni sebesar 83 persen bila dibandingkan dengan persentase responden yang berjenis kelamin laki-laki sebesar 17 persen.

Dilihat dari klasifikasi pekerjaan menunjukkan bahwa sebagian besar responden mahasiswa/pelajar hal ini dikarenakan lebih dominan para mahasiswa/pelajar yang menjadi responden dapat dilihat sebesar 59 persen yang secara umum bahwa tertarik dengan produk-produk yang disediakan. Perbedaan ini cukup signifikan dengan pekerjaan lainnya seperti ASN/TNI-POLRI sebesar 25 persen, karyawan/wiraswasta sebesar 16 persen.

Perhitungan koefisien jalur dilakukan dengan software SPSS 18.0 for Windows, diperoleh hasil yang ditunjukan pada Tabel 4. berikut. 
Tabel 5.

Hasil Analisis Jalur Struktural I

\begin{tabular}{|c|c|c|c|c|c|c|}
\hline \multirow{2}{*}{\multicolumn{2}{|c|}{ Model }} & \multicolumn{2}{|c|}{$\begin{array}{l}\text { Unstandardized } \\
\text { Coefficients }\end{array}$} & \multirow{2}{*}{$\begin{array}{c}\text { Standardized } \\
\text { Coefficients } \\
\text { Beta } \\
\end{array}$} & \multirow[b]{2}{*}{$\mathbf{t}$} & \multirow[b]{2}{*}{ Sig. } \\
\hline & & B & Std. Error & & & \\
\hline \multirow[t]{6}{*}{1} & (Constant) & 12.591 & 2.298 & & 5.480 & .000 \\
\hline & Kualitas Produk & .353 & .072 & .443 & 4.886 & .000 \\
\hline & R Square & 0,196 & & & & \\
\hline & Adjusted R Square & 0,188 & & & & \\
\hline & F Statistik & 23,876 & & & & \\
\hline & Signifikansi Uji F & 0,000 & & & & \\
\hline
\end{tabular}

Sumber: Data diolah, 2018

Berdasarkan hasil analisis jalur substruktur pertama seperti yang disajikan pada Tabel 5, maka dapat dibuat persamaan struktural sebagai berikut :

$$
\mathrm{Y}_{1}=0,433 \mathrm{X}+\mathrm{e}_{1}
$$

Tabel 6.

Hasil Analisis Jalur Struktural II

\begin{tabular}{|c|c|c|c|c|c|c|}
\hline \multirow{2}{*}{\multicolumn{2}{|c|}{ Model }} & \multicolumn{2}{|c|}{$\begin{array}{l}\text { Unstandardized } \\
\text { Coefficients }\end{array}$} & \multirow{2}{*}{$\begin{array}{l}\text { Standardized } \\
\text { Coefficients } \\
\text { Beta }\end{array}$} & \multirow[b]{2}{*}{$t$} & \multirow[b]{2}{*}{ Sig. } \\
\hline & & B & Std. Error & & & \\
\hline \multirow[t]{7}{*}{1} & (Constant) & 8.023 & 1.955 & & 4.103 & .000 \\
\hline & Kualitas Produk & .199 & .060 & .319 & 3.310 & .001 \\
\hline & Brand Image & 231 & .075 & 297 & 3.076 & .003 \\
\hline & R Square & 0,274 & & & & \\
\hline & Adjusted R Square & 0,259 & & & & \\
\hline & F Statistik & 18,301 & & & & \\
\hline & Signifikansi Uji F & 0,000 & & & & \\
\hline
\end{tabular}

Sumber: Data diolah, 2018

Berdasarkan hasil analisis jalur substruktur kedua seperti yang disajikan pada Tabel 5, maka dapat dibuat persamaan struktural sebagai berikut :

$$
\mathrm{Y} 2=0,319 \mathrm{X}+0,297 \mathrm{Y} 1+\mathrm{e}_{2}
$$

Pengaruh variabel kredibilitas kualitas produk (X) terhadap keputusan pembelian $\left(\mathrm{Y}_{2}\right)$ dengan brand image $\left(\mathrm{Y}_{1}\right)$ sebagai variabel mediasi sebesar:

Pengaruh tidak langsung $\quad=\beta_{2} \times \beta_{3}$

$$
\begin{aligned}
& =0,319 \times 0,297 \\
& =0,094
\end{aligned}
$$

Total pengaruh variabel $\mathrm{X}$ terhadap $\mathrm{Y}_{2}$ melalui $\mathrm{Y}_{1}$ dirumuskan sebagai berikut :

Total effect $=\beta_{1}+\left(\beta_{2} \times \beta_{3}\right)$

$$
\begin{aligned}
& =0,443+(0,319 \times 0,297) \\
& =0,537
\end{aligned}
$$

Berdasarkan model substruktur 1 dan substruktur 2, maka dapat disusun model diagram jalur akhir. Sebelum menyusun model diagram jalur akhir, terlebih dahulu dihitung nilai standar eror sebagai berikut: 


$$
\begin{aligned}
& P e_{i}=\sqrt{ } 1-R_{i}^{2} \\
& \mathrm{Pe}_{1}=\sqrt{ } 1-\mathrm{R}_{1}^{2}=\sqrt{ } 1-0,196=0,896 \\
& \mathrm{Pe}_{2}=\sqrt{1-\mathrm{R}_{2}}=\sqrt{1-0,274}=0,852
\end{aligned}
$$

Berdasarkan perhitungan pengaruh error (Pei), didapatkan hasil pengaruh error $\left(\mathrm{Pe}_{1}\right)$ sebesar 0,896 dan pengaruh error $\left(\mathrm{Pe}_{2}\right)$ sebesar 0,852. Hasil koefisien determinasi total adalah sebagai berikut :

$$
\begin{aligned}
\mathrm{R}^{2}{ }_{\mathrm{m}} & =1-\left(\mathrm{Pe}_{1}\right)^{2}\left(\mathrm{Pe}_{2}\right)^{2} \ldots \ldots \\
& =1-(0,896)^{2}(0,852)^{2} \\
& =1-(0,803)(0,726) \\
& =1-0,583=0,417
\end{aligned}
$$

Nilai determinasi total sebesar 0,417 mempunyai arti bahwa sebesar 41,7\% variasi Keputusan pembelian pada Produk Miniso di Kota Denpasar dipengaruhi oleh variasi kualitas produk dan brand image, sedangkan sisanya sebesar 58,3\% djelaskan oleh faktor lain yang tidak dimasukkan ke dalam model.

Hasil pengujian pada Tabel 5 diperoleh nilai koefisien $\mathrm{F} \leq 0,05$ dengan koefisien signifikan $0,000 \leq 0,05$, sehingga $\mathrm{H}_{0}$ ditolak dan $\mathrm{H}_{1}$ diterima. Hasil tersebut menunjukkan bahwa kualitas produk dan brand image berpengaruh secara simultan dan signifikan terhadap keputusan pembelian. Model persamaan struktural dalam penelitian ini telah memenuhi syarat goodness of fit melalui uji $\mathrm{F}$.

Berdasarkan hasil analisis pengaruh Kualitas produk terhadap Brand image diperoleh nilai Signifikansi sebesar 0,000 dengan nilai koefisien beta 0,443 . Nilai Signifikansi $0,000<0,05$ mengindikasikan bahwa $\mathrm{H}_{0}$ ditolak dan $\mathrm{H}_{1}$ diterima. Hasil ini mempunyai arti bahwa kualitas produk berpengaruh signifikan terhadap brand image Produk Miniso di Kota Denpasar.

Berdasarkan hasil analisis pengaruh kualitas produk terhadap keputusan pembelian diperoleh nilai signifikansi sebesar 0,000 dengan nilai koefisien beta 0,319. Nilai Signifikansi $0,000<0,05$ mengindikasikan bahwa $\mathrm{H}_{0}$ ditolak dan $\mathrm{H}_{1}$ diterima. Hasil ini mempunyai arti bahwa kualitas produk berpengaruh signifikan terhadap keputusan pembelian Produk Miniso di Kota Denpasar. .

Berdasarkan hasil analisis pengaruh brand image terhadap keputusan pembelian diperoleh nilai signifikansi sebesar 0,000 dengan nilai koefisien beta 0,297. Nilai Signifikansi $0,000<0,05$ mengindikasikan bahwa $\mathrm{H}_{0}$ ditolak dan $\mathrm{H}_{1}$ diterima. Hasil ini mempunyai arti bahwa brand image berpengaruh signifikan terhadap keputusan pembelian Produk Miniso di Kota Denpasar.

Perhitungan pengaruh antar variabel dirangkum dalam Tabel 6 sebagai berikut:

Tabel 7.

Pengaruh Langsung, Tidak Langsung, serta Pengaruh Total Kredibilitas Kualitas Produk (X), Brand Image ( $\left.\mathrm{Y}_{1}\right)$ dan Keputusan Pembelian

\begin{tabular}{cccc}
\hline $\begin{array}{c}\text { Pengaruh } \\
\text { Variabel }\end{array}$ & $\begin{array}{c}\text { Pengaruh } \\
\text { Langsung }\end{array}$ & $\begin{array}{c}\text { Pengaruh Tidak Langsung Melalui Brand } \\
\text { image } \\
\left(\mathbf{Y}_{\mathbf{1}}\right)(\boldsymbol{\beta} \mathbf{1} \times \mathbf{\beta} 3)\end{array}$ & Pengaruh Total \\
\hline $\mathrm{X} \rightarrow \mathrm{Y}_{1}$ & 0,443 & - & 0,443 \\
$\mathrm{X} \rightarrow \mathrm{Y}_{2}$ & 0,319 & 0,131 & 0,45 \\
$\mathrm{Y}_{1} \rightarrow \mathrm{Y}_{2}$ & 0,297 & - & 0,297 \\
\hline Sumber: & Data
\end{tabular}


Tabel 7. menunjukkan bahwa pengaruh langsung kualitas produk terhadap brand image adalah sebesar 0,433. Pengaruh langsung variabel kualitas produk terhadap keputusan pembelian sebesar 0,319. Hasil ini menyatakan bahwa variabel intervening yaitu variabel brand image menjadi variabel mediasi secara parsial karena mendapatkan hasil lebih dari 0 yang berarti masih ada faktor-faktor lain yang menjadi variabel mediasi. Pengaruh langsung variabel brand image terhadap keputusan pembelian sebesar 0,297. Hal ini berarti bahwa variabel keputusan pembelian lebih besar dipengaruhi oleh kualitas produk daripada brand image. Sedangkan pengaruh tidak langsung variabel kualitas produk terhadap keputusan pembelian melalui brand image sebesar 0,131. Pengaruh total variabel kualitas produk terhadap keputusan pembelian melalui brand image adalah sebesar 0,45. Simpulan bahwa lebih besar total pengaruh kualitas produk terhadap keputusan pembelian yang melalui brand image, daripada pengaruh langsung kualitas produk terhadap keputusan pembelian tanpa melalui variabel brand image.

Uji sobel merupakan alat analisis untuk menguji signifikansi dari hubungan tidak langsung antara variabel independen dengan variabel dependen yang dimediasi oleh variabel mediator. Uji Sobel dirumuskan dengan persamaan berikut dan dapat dihitung dengan menggunakan aplikasi Microsoft Excel 2007. Bila nilai kalkulasi Z lebih besar dari 1,96 (dengan tingkat kepercayaan 95 persen), maka variabel mediator dinilai secara signifikan memediasi hubungan antara variabel terikat dan variabel bebas.

Hasil pengujian $\mathrm{H}_{1}$ mengenai pengaruh kualitas produk terhadap keputusan pembelian diterima, ini menunjukkan bahwa kualitas produk secara signifikan berpengaruh terhadap keputusan pembelian produk Miniso di Kota Denpasar. Hasil ini bisa dikatakan bahwa semakin bagus kualitas produk yang dihasilkan oleh Miniso semakin tinggi keputusan pembelian pada produk Miniso.

Hasil penelitian ini diperkuat dengan penelitian sebelumnya yang dilakukan oleh Santoso et al. (2013), Saidani dan Arifin (2012), Yoher dan Santika (2018), Fernando dan Aksari (2018) dan membantah penelitian yang dilakukan oleh Rawung et al. (2015). Hal ini berarti, dengan kualitas produk yang semakin baik dimata konsumen maka dapat meningkatkan keputusan pembelian konsumen pada produk Miniso.

Hasil pengujian $\mathrm{H}_{2}$ mengenai pengaruh kualitas produk terhadap brand image diterima, ini menunjukkan bahwa kualitas produk secara signifikan berpengaruh terhadap brand image Miniso di Kota Denpasar. Hasil ini menunjukkan bahwa semakin bagus kualitas produk yang ditawarkan oleh Miniso semakin baik juga brand image yang ditanamkan oleh konsumen pada produk Miniso.

Hasil penelitian ini sesuai dengan penelitian sebelumnya yang dilakukan oleh Noerchoidah (2013), Nurdianto dan Yuniati (2013), Karlina dan Seminari (2015). Hal ini berarti dengan meningkatnya kredibilitas kualitas produk maka akan meningkatkan persepsi konsumen terhadap citra merek dari Miniso.

Hasil pengujian $\mathrm{H}_{3}$ menunjukkan bahwa pengaruh brand image terhadap keputusan pembelian diterima, ini menunjukkan bahwa brand image secara signifikan berpengaruh terhadap keputusan pembelian. Hasil ini menunjukkan bahwa 
semakin baik image Miniso maka semakin mampu mempengaruhi keputusan pembelian terhadap produk Miniso.

Hasil penelitian ini sesuai dengan penelitian sebelumnya yang dilakukan oleh Fristiana (2012), Malik et al. (2013), Sandhu et al. (2014), Dewi dan Aksari (2017), Arsyanto dan Rahmawati (2018) yang memperoleh hasil brand image berpengaruh signifikan terhadap keputusan pembelian. Ketertarikan atau minat akan membentuk suatu persepsi terhadap brand image suatu produk dalam proses pengambilan keputusan. Produk yang memiliki brand image yang baik akan menimbulkan keputusan pembelian pada produk Miniso.

Hasil pengujian $\mathrm{H}_{4}$ mengenai peran brand image dalam memediasi kualitas produk terhadap keputusan pembelian dengan menggunakan uji sobel membuktikan peran brand image memediasi secara signifikan memediasi pengaruh kualitas produk terhadap keputusan pembelian dengan hasil 2,57 $>1,96$. Hasil ini menunjukkan bahwa $\mathrm{H}_{4}$ dalam penelitian ini diterima, hal ini membuktikan bahwa brand image memiliki peran secara signifikan dalam memediasi pengaruh kualitas produk terhadap keputusan pembelian.

Hasil penelitian ini sesuai dengan penelitian sebelumnya yang dilakukan oleh Sagita (2013) dan Fianto et al. (2014) menunjukkan bahwa citra merek memiliki pengaruh signifikan terhadap keputusan pembelian. Penelitian lainnya dilakukan oleh Nurdianto dan Yuniati (2013), Alfiyah dan Maftukhah (2015) dalam penelitiannya menyatakan bahwa kualitas produk yang baik akan memberikan kepercayaan dan persepsi (citra) yang baik juga kepada konsumen dalam penggunaan produk yang kemudian menjadi motivasi terhadap konsumen untuk membuat keputusan pembelian. Semakin baik kualitas produk yang dimiliki maka akan menciptakan image yang positif bagi produk dan perusahaan dimata konsumen sehingga konsumen memutuskan untuk membeli produk Miniso.

Berdasarkan penelitian yang telah dilakukan sehingga dapat diketahui secara teoritis, hasil penelitian ini menekankan pada manfaat nyata untuk mendorong kualitas produk yang ditawarkan oleh perusahaan agar lebih baik sehingga bisa meningkatkan keputusan pembelian konsumen terhadap produk tersebut. Kualitas produk yang baik juga mempengaruhi image perusahaan. Bukan hanya image perusahaan saja namun image produk yang ditawarkan juga sangat berpengaruh sehingga meningkatkan keputusan pembelian konsumen. Hasil ini menunjukkan kualitas produk menjadi tolak ukur yang secara signifikan dapat meningkatkan brand image dan juga keputusan pembelian pada suatu perusahaan.

Penelitian ini diharapkan memberikan kontribusi empiris mengenai hubungan antara variabel kualitas produk, brand image dan keputusan pembelian bagi pengembangan ilmu pemasaran. Pengolahan data dilakukan dengan teknik analisis jalur (path analysis) untuk menguji model antar variabel-variabel yang telah ditetapkan berdasarkan teori. Selain itu, penelitian ini menggunakan Uji Sobel untuk menguji pengaruh tidak langsung variabel kualitas produk terhadap keputusan pembelian melalui variabel brand image. Hasil penelitian ini diharapkan dapat digunakan menambah referensi dan ilmu pengetahuan yang berkaitan dengan variabel kualitas produk, brand image, dan keputusan pembelian.

Penelitian ini diharapkan dapat digunakan bagi manajemen perusahaan Miniso dalam merancang strategi pemasaran berdasarkan kualitas produk guna 
meningkatkan brand image dan keputusan pembelian produk Miniso. Strategi yang dapat dilakukan oleh perusahaan yaitu meningkatkan kualitas produk dan terus melakukan inovasi sehingga Miniso menjadi lebih popular agar konsumen lainnya menjadi memutuskan untuk membeli produk Miniso.

Ruang lingkup pada penelitian terbatas pada wilayah Kota Denpasar, sehingga hasil penelitian ini tidak dapat digeneralisasikan untuk responden diluar wilayah Kota Denpasar. Penelitian ini hanya dilakukan dalam titik waktu tertentu (cross section), sedangkan lingkungan bersifat sangat dinamis sehingga penelitian dapat dilakukan kembali dimasa datang. Penelitian ini mendapatkan hasil dari variabel mediasi yang menunjukkan bahwa variabel mediasi ini masih mediasi secara parsial sehingga memungkinkan adanya variabel mediasi lainnya yang mempengaruhi kualitas produk terhadap keputusan pembelian.

\section{SIMPULAN}

Kualitas produk berpengaruh signifikan terhadap keputusan pembelian. Hasil ini berarti semakin tinggi kualitas produk maka semakin meningkatkan keputusan pembelian pada produk tersebut. Kualitas produk berpengaruh signifikan terhadap brand image. hasil ini berarti semakin tinggi kualitas produk maka semakin tinggi pula brand image yang dimiliki oleh produk dan perusahaan.

Brand image berpengaruh signifikan terhadap keputusan pembelian. Hasil ini berarti semakin tinggi citra merek yang dimiliki oleh produk maka akan meningkatkan keputusan pembelian pada produk. Brand image mampu memediasi pengaruh kualitas produk terhadap keputusan pembelian. Hal ini berarti bahwa brand image yang terbentuk pada produk Miniso turut mempengaruhi kualitas produk terhadap keputusan pembelian produk pada merek Miniso di Kota Denpasar.

Bagi pihak perusahaan Miniso, kedepannya dapat lebih meningkatkan kualitas produk dari segi daya tahan produk, kenyamanan produk saat digunakan oleh konsumen dan daya tarik produk yang bisa meningkatkan brand image yang telah di miliki oleh Miniso baik dari produk dan perusahaan sehingga konsumen memutuskan untuk membeli produk Miniso berulang kali. Bagi penelitian selanjutnya, diharapkan dapat memperluas luang lingkup penelitian dengan konsumen yang tersebar diberbagai wilayah. Penelitian selanjutnya juga bisa mengubah atau menggunakan objek penelitian ini dengan menggunakan variabel lain agar dapat memperkaya informasi yang diperoleh.

\section{REFERENSI}

Ackaradejruangsri, P. (2013). The effect of product quality attributes on Thai consumers ' buying decisions. Ritsumeikan Journal of Asia Pacific Studies, 33(1), 14-24. Retrieved from https://core.ac.uk/download/pdf/60549183.pdf

Afroz, N. (2013). Effect of Advertisement on Buying Responses of CouplesThrough Brand Survey Technique. Social Science International, 29(1), 129-140. Retrieved from https://web.a.ebscohost.com/abstract?direct=true\&profile=ehost\&scope=site \&authtype $=$ crawler\&jrnl $=09701087 \& A N=89881021 \& \mathrm{~h}=\mathrm{hMEb5uFWLN1lh}$ q3XxLcopQFjmxeCCxac9L9ZIujzyZMMryem4j5\%2F8TNa7NlaQzyu4EJr RL2RxZzX4UWN5alvGQ\%3D\%3D\&crl=c\&resultNs=AdminWebAuth\&re 
sultLocal=ErrCrlNotAuth\&crlhashurl=login.aspx\%3Fdirect $\% 3$ Dtrue $\% 26 \mathrm{pr}$ ofile\%3Dehost\%26scope\%3Dsite\%26authtype\%3Dcrawler\%26jrnl\%3D097 01087\%26AN\%3D89881021

Aldi, A. (2012). Pengaruh Citra Merk dan Kualitas Produk Terhadap Keputusan Pembelian Konsumen. Universitas Negeri Yogyakarta. Retrieved from https://eprints.uny.ac.id/8572/

Alfiyah, N., \& Maftukhah, I. (2015). Pengaruh Celebrity Endorser dan Kualitas Produk Terhadap Keputusan Pembelian Melalui Citra Merek Pada Kosmetik Wardah di Kota Semarang. Management Analysis Journal, 4(2), 2252-2262. Retrieved from https://lib.unnes.ac.id/22068/1/7311411059s.pdf

Alma, B. (2013). Manajemen Pemasaran dan Pemasaran Jasa. Bandung: Alfabeta.

Armstrong, K. (2015). Marketing an Introducing Prentice Hall (12th ed.). England: Pearson Education Limited.

Arsyanto, M. T., \& Rahmawati. (2018). Analisis Pengaruh Positioning Produk dan Citra Merk Terhadap Keputusan Pembelian ( Studi pada Civitas Akademika di Universitas Kahuripan Kediri dan Universitas Islam Kediri ). Journal Inovasi Bisnis Dan Manajemen Indonesia, 2(1), 101-116. Retrieved from https://inobis.org/ojs/index.php/jurnal-inobis/article/view/64/54

Dabija, D.-C. (2013). Empirical Research On Brand Awareness In Grocery Retailing. Review of Economic Studies and Research Virgil Madgear, 3(1), 21-36. Retrieved from https:/www.researchgate.net/publication/ 260982942_Empirical_Research_on_Brand_Awareness_in_Grocery_Retaili ng

Dewi, K. A. A., \& Aksari, N. M. A. (2017). Peran brand Image dalam Memediasi Pengaruh Green Marketing terhadap Keputusan Pembelian Produk Oriflame. E-Journal Manajemen Unud, 6(11), 6029-6060. Retrieved from https://ojs.unud.ac.id/index.php/Manajemen/article/view/33384/21236

Dewi, N. N. A. S. T. C., \& Suasana, I. G. A. K. G. (2014). Pengaruh Kualitas Produk, Citra Merek, Dan Materialisme Terhadap Loyalitas Merek Pengguna Produk Apple Di Kota Denpasar. E-Journal Manajemen Unud, 3(3), 714-732. Retrieved from https://ojs.unud.ac.id/index.php/Manajemen/ article/view/7282/6185

Fatlahah, A. (2013). Pengaruh Kualitas Produk dan Citra Merek Terhadap Keputusan Pembelian Es Krim Wall's Magnum. Jurnal Ilmu Manajemen, 1(2), 472-485. Retrieved from http://jurnalmahasiswa.unesa.ac.id/index.php/ jim/article/download/2974/5818

Fernando, M. F., \& Aksari, N. M. A. (2018). Pengaruh Kualitas Produk, Harga, Promosi, dan Distribusi Terhadap Keputusan Pembelian Produk Santitary Ware Toto Di Kota Denpasar. E-Journal Manajemen Unud, 7(1), 441-469. https://doi.org/https://doi.org/10.24843/EJMUNUD.2018.v7.i01.p17 
Fianto, A. Y. A., Hadiwidjojo, D., Aisjah, S., \& Solimun. (2014). The Influence of Brand Image on Purchase Behaviour Through Brand Trust. Business Management and Strategy, 5(2), 58-76. https://doi.org/10.5296/bms. v5i2.6003

Fristiana, D. A. (2012). Pendahuluan. Jurnal Ilmu Administrasi Bisnis, 1(1), 1-9. Retrieved from https://ejournal3.undip.ac.id/index.php/jiab/article/view/ $839 / 814$

Ghanimata, F., \& Kamal, M. (2012). ). Analisis Pengaruh Harga, Kualitas Produk, Dan Lokasi Terhadap Keputusan Pembelian (Studi pada Pembeli Produk Bandeng Juwana Elrina Semarang). Diponegoro Journal of Management, 1(2), 1-10. Retrieved from http://eprints.undip.ac.id/36184/

Hingley, M., Walley, K., Lindgreen, A., Custance, P., \& Taylor, S. (2007). The importance of brand in the industrial purchase decision: a case study of the UK tractor market. Journal of Business \& Industrial Marketing, 22(6), 383393. https://doi.org/10.1108/08858620710780145

Karlina, N. P. N., \& Seminari, N. K. (2015). Pengaruh Citra Merek dan Kualitas Produk Terhadap Keputusan Pembelian Produk Pt. Karya Pak Oles Tokcer Denpasar. E-Journal Manajemen Unud, 4(6), 1610-1623. Retrieved from https://ojs.unud.ac.id/index.php/Manajemen/article/view/12229/9561

Khandelwal, U., Bajpai, N., \& Sharma, J. P. (2014). Purchase Intention of Indian Consumers on Online Travel Buying Decision: A Comparative Study on Metro And Non-Metro City. International Journal of Hospitality \& Tourism Systems, 5(2), 13-22. Retrieved from https:/www.researchgate.net/ publication/253330541_Purchase_Intention_of_Indian_Consumers_on_Onli ne_Travel_Buying_Decision_A_Comparative_Study_on_Metro_and_NonMetro_City/download

Kotler, P. (2002). Manajemen Pemasaran (Millenium). Jakarta: Prenhallindo.

Kotler, P., \& Keller, K. L. (2016). Marketing Managemen. England: Pearson Education Limited.

Malik, M. E., Ghafoor, M. M., \& Iqbal, H. K. (2013). Impact of Brand Image and Advertisement on Consumer Buying Behavior. World Applied Sciences Journal 23, 23(1), 117-122. https://doi.org/10.5829/idosi.wasj.2013. 23.01.824

Mamang, S., \& Sophia. (2013). Perilaku Konsumen Pendekatan Praktis Disertai : Himpunan Jurnal Penelitian. Yogyakarta: Andi Offset.

Mendrofa, Y. B. (2010). Effect of Product Knowledge and Brand Image To Purchase Intention With HP Laptop Brand Price Discount As Variable Moderated In Surabaya. Journal Of Management, 1(4), 21-36. Retrieved from

http://journal.wima.ac.id/index.php/JUMMA/article/download/355/328

Musay, F. (2013). Pengaruh Brand Image terhadap Keputusan Pembelian (Survei pada Konsumen KFC Kawi Malang). Jurnal Administrasi Bisnis, 3(2), 1-7. 
Retrieved from http://administrasibisnis.studentjournal.ub.ac.id/index.php/ jab/article/view/141/197

Noerchoidah. (2013). Analisis Pengaruh Harga , Kualitas Produk Dan Iklan Terhadap Brand Image Dan Keputusan Pembelian Sepeda Motor Merek Kawasaki. Jurnal WIGA, 3(1), 48-60. Retrieved from https://media.neliti.com/media/publications/36645-ID-analisis-pengaruhharga-kualitas-produk-dan-iklan-terhadap-brand-image-dan-keput.pdf

Nurdianto, D., \& Yuniati, T. (2013). Pengaruh Kualitas Produk dan Citra Sebagai Variabel Intervening terhadap Keputusan Konsumen dalam Membeli Motor Honda. Jurnal Ilmiah Dan Riset Manajemen, 2(10), 1-29. Retrieved from https://ejournal.stiesia.ac.id/jirm/article/view/392

Rawung, D. R., Oroh, S. G., \& Sumarauw, J. S. (2015). Analisis Kualitas Produk, Merek Dan Harga Terhadap Keputusan Pembelian Sepeda Motor Suzuki Pada Pt. Sinar Galesong Pratama Manado. Jurnal EMBA, 3(3), 1298-1308. Retrieved from https://ejournal.unsrat.ac.id/index.php/emba/article/view/10413/9999

Sagita, F. E. (2013). Pengaruh Brand Image dan Harga Terhadap Keputusan Pembelian Ulang Produk Kentuky Fried Chicken (KFC) di Cabang Bakso Grand Mall. Jurnal Manajemen, 2(2), 1-8. Retrieved from ejournal.unp.ac.id/students/index.php/mnj/article/view/535

Saidani, B., \& Arifin, S. (2012). Pengaruh Kualitas Produk dan Kualitas Layanan Terhadap Kepuasan Konsumen dan Minat Beli Pada Ranch Market. Jurnal Riset Manajemen Sains Indonesia (JRMSI), 3(1), 1-22. Retrieved from http://journal.unj.ac.id/unj/index.php/jrmsi/article/download/766/675

Sandhu, M. A., Mahasan, S. S., \& Rehman, A. U. (2014). The Impact Of Brand Image and Celebrity Endorsement On Consumers Purchase Preference for Fashion Product. Journal Indian Stream Research, 4(2), 1-10. Retrieved from http://www.citeulike.org/group/108/article/13099366

Santoso, K. W., Waluyo, H. J., \& Listyorini, S. (2013). Pengaruh Kualitas Produk, Harga dan Promosi terhadap Keputusan Pembelian Permen Tolak Angin di Semarang. Diponegoro Journal of Social And Politic, 3(1), 1-11. Retrieved from https://ejournal3.undip.ac.id/index.php/jiab/article/download/4378/4225

Tjiptono, F. (2016). Pemasaran Jasa (Prinsip, Penerapan dan Penelitian). Yogyakarta: Andi.

Utama, I. G. N. K. Y. (2014). Faktor- faktor yang mempengaruhi Konsumen dalam Keputusan Pembelian Smartphone Blackberry studi kasus Kota Denpasar. E-Journal Manajemen Unud, 3(3), 679-693. Retrieved from https://ojs.unud.ac.id/index.php/Manajemen/article/view/6949/6183

Vanessa, I., \& Arifin, Z. (2017). Pengaruh Citra Merek (Brand Image) dan Harga Terhadap Keputusan Pembelian Konsumen. Jurnal Administrasi Bisnis (JAB), 51(1), 44-48. Retrieved from http://administrasibisnis.studentjournal .ub.ac.id/index.php/jab/article/download/2105/2497 
Ni Made Dwi Sanjiwani, Peran Brand Image...

Yoher, R. A., \& Santika, I. W. (2018). Pengaruh Product Quality, Brand Equity dan Iklan terhadap Keputusan Pembelian pada Produk Obat Nyamuk Vape. E-Journal Manajemen Unud, 7(2), 674-700. https://doi.org/https:// doi.org/10.24843/EJMUNUD.2018.v7.i02.p05 